\title{
Perawatan endodontik non bedah pada gigi molar pertama rahang bawah kiri nekrosis pulpa dengan lesi periapikal
}

\author{
Widy $^{1}$, Anna Muryani ${ }^{*}$ \\ ${ }^{1}$ Rumah Sakit Angkatan Laut Samuel J Moeda Kupang, Indonesia \\ ${ }^{2 *}$ Departemen Konservasi Gigi, Fakultas Kedokteran Gigi Universitas Padjadjaran, Indonesia
}

*Korespondensi: anna.murvani@fkq.unpad.ac.id

Submisi: 27 Juli 2018; Penerimaan: 28 November 2020; Publikasi online: 30 November 2020 DOI: $10.24198 / \mathrm{jkg} . \mathrm{v} 32 \mathrm{i} 2.18035$

\begin{abstract}
ABSTRAK
Pendahuluan: Perjalanan infeksi penyakit pulpa bisa menjalar terus ke saluran akar dan jaringan periapikal sehingga membuat lesi periapikal. Lesi periapikal terutama pada gigi molar menjadi tantangan bagi dokter gigi karena lebih disarankan perawatan endodontik bedah dibandingkan dengan non bedah. Tujuan laporan kasus ini membahas keberhasilan perawatan endodontik non bedah pada gigi nekrosis pulpa dengan lesi periapikal. Laporan kasus: Kasus ini merupakan gigi molar pertama rahang bawah kiri dengan lesi periapikal pada pasien laki-laki berusia 25 tahun. Saluran akar dipreparasi saluran akar dan diirigasi dengan NaOCL 5,25\% dan EDTA 18\% disertai agitasi dan menghasilkan saluran akar yang bersih, Saluran akar setelah bersih dan kering diberi medikamen kalsium hidroksida. Evaluasi klinis dilakukan setiap 2 minggu sampai tidak adanya keluhan dari pasien. Pengisian saluran akar dilakukan secara hermetis. Pemeriksaan klinis dan radiografi setelah 1 bulan memperlihatkan perbaikan dari lesi periapikal. Tahapan preparasi biomekanis pada perawatan endodontik non bedah pada gigi yang mengalami nekrosis pulpa dengan lesi periapikal apabila dilakukan dengan optimal dapat membantu medikamen kalsium hidroksida berpenetrasi baik pada jaringan periapikal dan membuat proses perbaikan pada lesi periapikal. Pengisian yang hermetis membantu sterilisasi saluran akar tetap terjaga dengan penutupan yang rapat. Radiografi merupakan metode yang paling banyak digunakan untuk mendeteksi lesi periapikal. Gambaran radiografi seperti perubahan densitas sekitar lesi, pembentukan kembali trabekula dan lamina dura menandakan adanya penyembuhan, terutama ketika dikaitkan dengan hasil klinis bahwa gigi tersebut tidak memiliki gejala dengan jaringan lunak yang sehat. Simpulan: Perawatan endodontik non bedah pada gigi molar pertama rahang bawah kiri nekrosis pulpa dengan lesi periapikal menunjukan keberhasilan dengan terjadinya penyembuhan jaringan keras
\end{abstract}

Kata kunci: Perawatan endodontik non bedah, lesi periapikal, molar pertama, nekrosis pulpa

\section{Non-surgical endodontic treatment of left mandibular first molar pulp necrosis} with periapical lesions

\section{ABSTRACT}

Introduction: The pulp disease infection course can spread to the root canals and periapical tissues, which creates periapical lesions. Periapical lesions, especially molar teeth, are a challenge for dentists because surgical endodontic treatment is more recommended than non-surgical treatment. This case report was aimed to discuss the successful non-surgical endodontic treatment of pulp necrotic teeth with periapical lesions. Case report: This case was discussing the left mandibular first molar with a periapical lesion in a 25-years-old male patient. Root canals was prepared and irrigated with $5.25 \% \mathrm{NaOCL}$ and $18 \%$ EDTA, followed by agitation, which resulted in clean root canals. After being cleaned and dried, the calcium hydroxide medicament was given. Clinical evaluation was carried out every two weeks until there were no complaints from the patient. Root canal filling was performed hermetically. After one month, clinical and radiographic examination showed improvement of the periapical lesions. Optimal biomechanical preparation stage in non-surgical endodontic treatment of teeth with pulp necrosis with periapical lesions can help the calcium hydroxide medicament penetrate well in the periapical tissue, thus makes the process of repairing the periapical lesions. A hermetic filling helps to maintain the root canal sterilisation by keeping it tightly closed. Radiography is the most widely used method for detecting periapical lesions. Radiographs such as changes in density around the lesion, trabecular reconstitution and lamina dura, indicate healing, especially when associated with clinical results since the tooth is asymptomatic with healthy soft tissue. Conclusion: Non-surgical endodontic treatment of left mandibular first molar with pulp necrosis with periapical lesions showed success result with hard tissue healing.

Keywords: Non-surgical endodontic treatment, periapical lesions, first molar, pulp necrosis. 


\section{PENDAHULUAN}

Pembentukan lesi periapikal belum sepenuhnya dipahami meskipun dapat diterima bahwa nekrosis pulpa dengan lesi periapikal pulpa menghasilkan lingkungan yang ideal untuk pertumbuhan mikroorganisme yang pada akhirnya melepaskan toksin ke jaringan periapikal, menginduksi reaksi peradangan dan pada akhirnya membentuk lesi periapikal. ${ }^{1}$ Tingkat keberhasilan perawatan saluran akar bergantung Faktorfaktor yang berpengaruh diantaranya diagnosis pra-operasi dan jenis perawatannya dengan keberhasilan terbesar yaitu pulpektomi dan yang terendah yaitu perawatan ulang saluran akar yang sudah dirawat endodontik dengan radiolusensi periapikal. $^{2}$

Perawatan saluran akar bertujuan untuk menghilangkan bakteri dari sistem saluran akar yang terinfeksi dan menciptakan lingkungan yang baik untuk penyembuhan. Penelitian telah menunjukkan bahwa tidak mungkin untuk mencapai ruang saluran akar yang bebas dari bakteri, bahkan setelah cleaning, shaping dan irigasi yang menyeluruh dengan desinfektan atau antiseptik, sehingga masih adanya kekhawatiran mengenai mikroorganisme yang masih tersisa dalam saluran akar terutama pada gigi molar yang memiliki saluran akar lebih dari satu dan anatomi saluran akar yang bervariasi. Bakteri yang tersisa dapat dihilangkan atau dicegah dengan menggunakan medikamen interappointment seperti kalsium hidroksida pada saluran akar. ${ }^{3}$
Metode lain untuk menghilangkan mikroorganisme yang tersisa adalah dengan melakukan pengisian saluran akar lengkap segera setelah preparasi dan irigasi saluran akar. Mikroorganisme yang tersisa dapat dibunuh oleh aktivitas antimikroba dari obat pengisi atau kekurangan nutrisi dan ruang untuk berkembang biak. Mikroorganisme yang dihilangkan ketika perawatan saluran akar memberikan prediksi penyembuhan lesi periapikal yang baik. ${ }^{4}$

Potensi penyembuhan untuk gigi yang dirawat dalam satu atau dua kunjungan dengan pemakaian medikamen saluran akartampakserupa Beberapa penelitian melaporkan keberadaan mikroorganisme yang tersisa setelah cleaning, shaping dan pemakaian kalsium hidroksida tidak berkaitan secara langsung dengan penyembuhan. ${ }^{3}$ Tujuan laporan kasus ini membahas keberhasilan perawatan endodontik non bedah pada gigi nekrosis pulpa dengan lesi periapikal.

\section{LAPORAN KASUS}

Seorang laki-laki berusia 25 tahun datang ke RSGM UNPAD dengan keluhan gigi berlubang pada regio rahang bawah kiri sejak kurang lebih 1 tahun yang lalu, ada riwayat nyeri spontan dan pembengkakan pada area gigi tersebut. Pemeriksaan klinis menunjukkan adanya karies mencapai pulpa pada gigi 36 , tes vitalitas negatif, tes perkusi positif, dan tidak ada kegoyangan (Gambar 1A). Hasil pemeriksaan radiografi terdapat lesi periapikal pada gigi 36 (Gambar 1B).

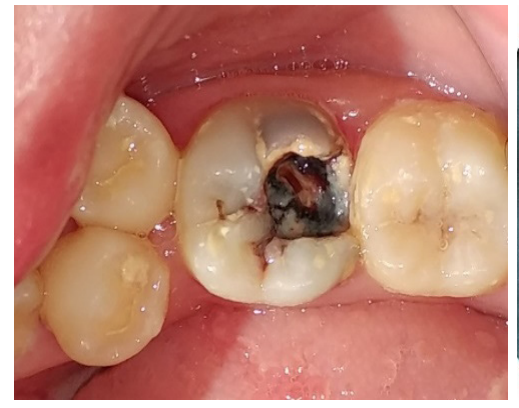

A

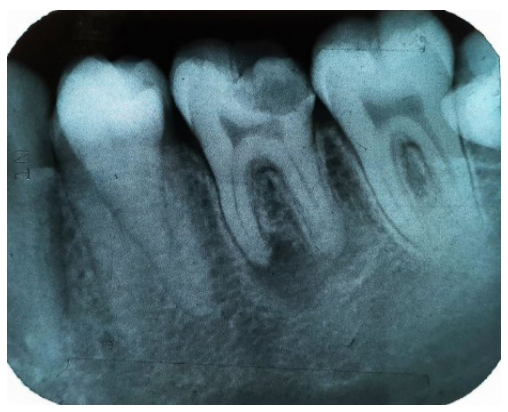

B

Gambar 1. A. Gambaran klinis pre-operatif gigi molar pertama bawah kiri; B. Radiografi pre-operatif menunjukkan adanya lesi periapikal pada gigi 36.(Sumber: Dokumentasi sendiri)

Rencana perawatan ditentukan setelah melihat hasil pemeriksaan klinis yaitu perawatan endodontik non bedah pada gigi 36. Perawatan dimulai dengan pemasangan rubber dam sebagai tindakan isolasi kemudian dilakukan preparasi akses kavitas dan panjang kerja ditentukan dengan menggunakan apex locator.

Preparasi saluran akar dilakukan dengan menggunakan jarum hand file dan rotary. Selama proses preparasi, saluran akar diirigasi dengan 
menggunakan larutan $\mathrm{NaOCl} 5,25 \%$ serta EDTA $18 \%$ kemudian saluran akar diisi dengan kalsium hidroksida sebagai medikamen saluran akar lalu diberikan tambalan sementara dan pasien diinstruksikan untuk kontrol kembali 2 minggu kemudian. Pasien tidak memiliki keluhan pada saat kunjungan kedua namun pemeriksaan perkusi masih menunjukan hasil yang positif sehingga saluran akar pun dibersihkan kembali dari medikamen saluran akar, diirigasi dengan larutan EDTA $18 \%$ dan larutan $\mathrm{NaOCl} 5,25 \%$ disertai agitasi, kemudian saluran akar diberikan kalsium hidroksida kembali sebagai medikamen saluran akar dan pasien diinstruksikan untuk kontrol kembali 2 minggu kemudian. Saluran akar kemudian dilakukan persiapan pengisian saluran akar dengan gutta percha dan sealer setelah evaluasi pasien tidak memiliki keluhan pada kunjungan ketiga dan pemeriksaan perkusi menunjukkan hasil yang negative. Uji coba gutta percha dilakukan foto radiografi dengan mastercone (Gambar 2A) dan dilakukan pengisian saluran akar dengan gutta percha dan sealer (Gambar 2B) dan gigi dilakukan restorasi pasca perawatan endodontik (Gambar 3A).Pasien tidak memiliki keluhan 1 bulan setelah dilakukan obturasi, pemeriksaan

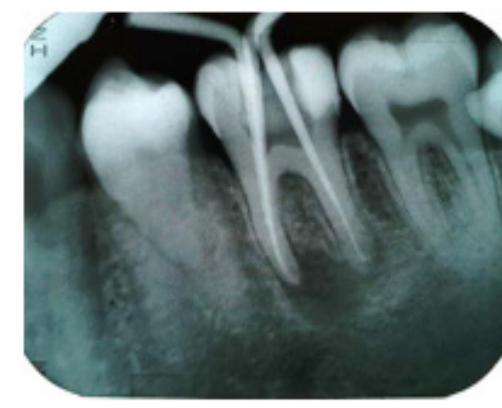

A

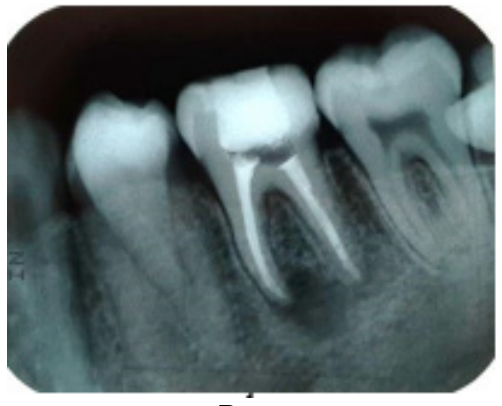

Gambar 2. A. Radiografi trial pengisian dengan mastercone; B. Radiografi obturasi saluran akar dengan gutta percha dan sealer. (Sumber: Dokumentasi sendiri)

klinis perkusi menunjukkan hasil yang negatif, tidak adanya kegoyangan pada gigi dan jaringan sekitar tampak tidak ada kelainan. Foto radiografi kontrol pengisian dilakukan, dari hasil pemeriksaan radiografi menunjukkan adanya perbaikan lesi periapikal pada regio gigi 36 (Gambar 3B). Pasien menyetujui kasusnya untuk dipublikasikan dengan menandatangani informed consent. Laporan kasus ini telah mendapatkan persetujuan dari pasien melalui informed consent yang diberikan

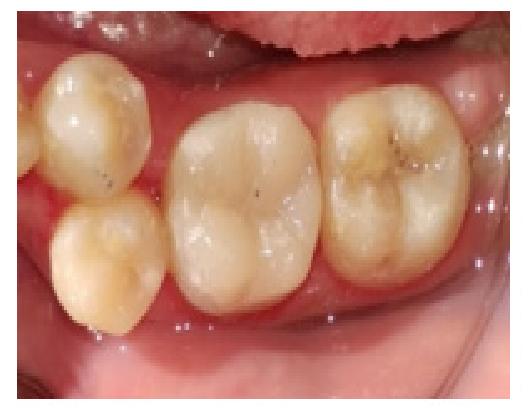

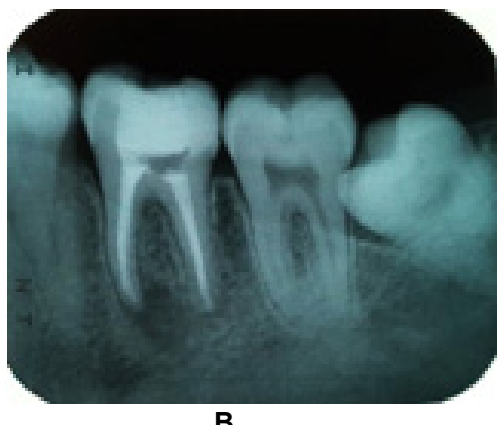

Gambar 3. A. Restorasi akhir pada gigi 36; B. Radiografi kontrol pengisian setelah 1 bulan menunjukkan adanya perbaikan lesi periapikal.(Sumber: Dokumentasi sendiri)

\section{PEMBAHASAN}

Nekrosis pulpa dengan lesi periapikal pulpa akibat trauma atau karies menciptakan lingkungan yang menguntungkan bagi bakteri untuk berkembang biak hal ini adalah alasan utama terbentuknya lesi periapikal. Diagnosis yang tepat dari lesi ini hanya dapat dilakukan melalui pemeriksaan histologis, tetapi diagnosis awal dapat dibuat berdasarkan pemeriksaan klinis dan radiografi. ${ }^{5}$ Pemeriksaan klinis dan pemeriksaan radiografi adalah prosedur yang paling umum digunakan untuk menentukan hasil dari perawatan saluran akar. Pemeriksaan histologis jaringan periapikal dengan intervensi bedah adalah metode lain untuk evaluasi keberhasilan atau kegagalan 
perawatan saluran akar. Hilangnya nyeri, pembengkakan, hilangnya sinus tract dan tidak adanya destruksi jaringan lunak adalah indikator keberhasilan perawatan saluran akar. Pada gigi dengan pulpa nekrotik, perawatan dianggap berhasil jika gigi tersebut tetap asimtomatik, lesi periapikalnya sembuh, dan tidak memunculkan lesi periapikal baru pada gigi yang telah dirawat. ${ }^{6}$

Tujuan utama perawatan saluran akar nonbedah adalah mengembalikan gigi dalam keadaan sehat dan berfungsi dengan baik tanpa adanya intervensi bedah. ${ }^{7}$ Inflamasi pada lesi periapeks pada awalnya dirawat dengan prosedur endodontik non-bedah. ${ }^{8}$ Intervensi bedah disarankan setelah perawatan saluran akar non-bedah gagal. ${ }^{9,10}$ Persentase penyembuhan total dan parsial lesi periapeks setelah perawatan saluran akar nonbedah cukup besar, yaitu $94,4 \%{ }^{11}$

Medikamen saluran akar kalsium hidroksida lebih efektif terhadap bakteri anaerob dibandingkan penggunaan paramonochlorophenol. pH kalsium hidroksida yang tinggi oleh karena pelepasan ion hidroksida mampu mengubah integritas struktural membran sitoplasma bakteri. ${ }^{12}$ Kalsium hidroksida memiliki efek tidak langsung pada mikroorganisme anaerobik saluran akar karena reaksi a ntara ion kalsium dan karbon dioksida. Kalsium hidroksida juga memiliki kemampuan untuk menghidrolisis bagian lipopolisakarida bakteri (LPS), sehingga menonaktifkan aktivitas biologis dan mengurangi efek dari lipopolisakarida. ${ }^{13}$

Meskipun cairan kistik mengandung kristal kolesterol, pergantian medikamen di dalam saluran akar yang dilakukan setiap dua sampai tiga minggu, serta diikuti oleh pengisian telah menyebabkan penyembuhan lesi secara lengkap dalam waktu 12 sampai 15 bulan. ${ }^{14-16}$ Siquierra ${ }^{16-19}$ menyatakan bahwa waktu yang diperlukan kalsium hidroksida untuk meningkatkan $\mathrm{pH}$ menjadi 9 di dalam saluran akar dan jaringan periapeks adalah minimal 14 hari dan mencapai $\mathrm{pH} 12$ dalam 1-3 bulan. Pada kasus ini lesi mengalami pengecilan ukuran dan hilangnya pembengkakan terjadi pada bulan kedelapan, dan dibutuhkan observasi serta kontrol untuk penyembuhan lengkap pada 3 bulan, 6 bulan, serta 1 tahun setelah pengisian.

Teknik pembentukan saluran akar yang digunakan menggunakan pada kasus ini dengan adalah teknik stepback menggunakan file dengan kerucut $2 \%$, agar tidak memperlemah struktur dentin akar di koronal karena saluran akar pada $1 / 3$ koronal sudah tampak lebar dengan struktur dentin yang tipis, namun tetap dapat untuk mempertahankan stop apical.

Sistem saluran akar yang bersih dari infeksi menjadi hal yang amat penting untuk memperbaik lesi periapikal yang besar. Pembersihan dan pembentukan yang adekuat dengan irigasi larutan $\mathrm{NaOCl} 2,5 \%$, dengan agitasi sonik, dan EDTA 18\%, serta pemberian campuran kalsium hidroksida $\left(\mathrm{Ca}(\mathrm{OH})_{2}\right)$ dan klorheksidin $2 \%$ sebagai medikamen saluran akar sangat direkomendasikan. ${ }^{10-13}$

Larutan irigasi yang dipakai adalah $\mathrm{NaOCl} 2,5 \%$ karena memiliki efek anti mikroba mampu memutus rantai protein dan merusak aktivitas sintesis DNA bakteri, sebagai lubrikasi. Penggunaan larutan EDTA 18\% yang efektif untuk menghilangkan smear layer terutama menghilangkan komponen anorganik. ${ }^{17-19}$ Agitasi sonik (Endoactivator,Dentsply) memiliki tujuan untuk meningkatkan efektifitas irigan dalam membersihkan sistem saluran akar (fenomena hidrodinamik). Fenomena hidrodinamik telah diidentifikasi sebagai cara yang dapat meruntuhkan perlekatan lapisan smear. Tujuan agitasi cairan adalah untuk menghasilkan kavitasi, aliran akustik dan aliran mikro dengan aman pada irigan di dalam saluran akar. ${ }^{19}$ Pada kasus ini agitasi sonik ini juga dapat membantu mengangkat residu $\mathrm{CaOH} 2$ lama yang akan diganti dengan yang baru.

Evaluasi radiologis adalah metode yang banyak digunakan untuk mendeteksi lesi periapikal. Lesi periapikal dapat dideteksi secara radiografi ketika adanya kehilangan tulang alveolar disertai keterlibatan tulang kortikal selama proses perkembangan patologis periapikal. Gambaran radiografi seperti perubahan densitas sekitar lesi, reformasi trabekula dan lamina dura menandakan adanya suatu penyembuhan, terutama ketika dikaitkan dengan hasil klinis bahwa gigi tersebut tidak memiliki gejala dengan jaringan lunak yang sehat. $^{20-21}$

Perubahan densitas tulang dalam radiografi adalah gambaran dari suatu peradangan yang jelas. Densitas tulang ini dapat dinilai dengan menggunakan indeks periapikal (PAI) yang dikembangkan oleh Orstavik. Indeks ini relatif subjektif, karena gradasi yang samar dan variabilitas potensial tergantung pada jenis proyeksi radiografi yang terlibat. PAI telah digunakan dalam penelitian 
untuk mengidentifikasi dan mengevaluasi secara radiografi gigi dengan lesi periapikal, terdiri dari skala 1-5 mulai dari jaringan sehat hingga periodontitis yang parah meliputi skala 1 artinya nilai normal, skala 2 artinya perubahan minor pada tulang, skala 3 artinya perubahan tulang dengan kehilangan mineral, skala 4 artinya periodontitis dengan area radiolusen yang jelas, dan skala 5 artinya periodontitis parah dengan eksaserbasi. ${ }^{2}$

Urutan kejadian yang mengarah kepada perbaikan lesi periapikal belum dipelajari secara ekstensif. Berdasarkan proses yang terlibat dalam perbaikan area yang terlibat setelah penghilangan iritan, respon inflamasi menurun dan jaringan pembentuk sel (fibroblas dan sel endotel) meningkat, akhirnya terjadi reorganisasi dan pematangan jaringan. Tulang yang diresorpsi digantikan oleh tulang baru; sementum dan dentin yang teresorbsi diperbaiki oleh sementum seluler.

Ligamen periodontal yang merupakan jaringan pertama yang terpengaruh adalah yang terakhir dikembalikan ke struktur normal. Pemeriksaan histologi penyembuhan lesi periapikal menunjukkan bukti penyembuhan dalam bentuk deposisi sementum, peningkatan vaskularisasi, dan peningkatan aktivitas fibrobastik dan osteoblastik. Penelitian telah menunjukkan bahwa beberapa sitokin memainkan peran penting selama penyembuhan lesi periapikal. ${ }^{6}$

Limfosit $T$ yang diaktifkan secara khusus menghasilkan sejumlah sitokin, beberapa di antaranya meningkatkan aktivasi, proliferasi, dan pematangan limfosit $B$ untuk menjadi sel-sel plasma yang memproduksi imunoglobulin khusus untuk bakteri saluran akar. Aktivasi makrofag dimediasi oleh interferon- $\mathrm{Y}$ (INF- $\mathrm{Y}$ ) yang dihasilkan juga oleh sel-sel ini. Makrofag aktif menghasilkan IL-1 dan IL-8 yang penting untuk aktivasi PMN. Bakteri endotoksin (LPS) dapat secara langsung mengaktifkan makrofag. Resorpsi tulang pada granuloma apikal dimediasi oleh IL-1 $\beta$ (produk makrofag aktif) dan oleh TNF- $\beta$ (produk limfosit $T$ aktif). Ini dapat dianggap sebagai efek samping negatif dari proses perlindungan yang sedang berlangsung di granuloma apikal.$^{22}$

Sitokin TNF $\beta$ dan IL-1 $\beta$, yang diproduksi oleh limfosit $T$ dan makrofag yang diaktifkan pada lesi, berfungsi sebagai sinyal utama utama yang menginduksi resorpsi tulang osteoklastik dalam granuloma apikal. Tulang disekitar lesi periapikal merupakan sumber yang kaya akan sel osteoprogenitor, bersama-sama dengan produksi EGF, IGF, TGF $\beta$, PDGF, dan BMP dapat memberikan potensi osteoblastik. Setelah bakteri dieliminasi dari saluran akar, terjadi pengurangan secara bertahap dari produksi TNF $\beta$ dan IL-1 $\beta$, lalu potensi osteogenik mulai mendominasi dan menyebabkan penyembuhan lesi oleh aposisi tulang baru. ${ }^{22}$

Pembentukan tulang di daerah apikal, sebagaimana tempat lain di tubuh, tergantung pada aktivitas osteoblas, suatu sel pembentuk tulang. Osteoblas berasal dari stem sel mesenkimal di sumsum tulang, sel ini diinduksi untuk berdiferensiasi dan meningkatkan selsel osteoprogenitor di bawah pengaruh bone morphogenetic protein (BMP). Faktor pertumbuhan seperti transforming growth factor $\beta$ (TGF $\beta$ ), fibroblast-derived growth factor (FGF), BMP, platelet-derived growth factor (PDGF), dan colonystimulating factor (CSF) dapat menginduksi danatau meningkatkan proliferasi yang merupakan sinyal kemotaksis untuk sel osteoprogenitor.

Sel osteoprogenitor dapat terakumulasi pada lokasi pembentukan tulang sebagai hasil dari proliferasi, daya tarik kemotaksis sel osteoprogenitor dari daerah yang berdekatan, atau keduanya. ${ }^{11}$ Beberapa lesi tidak sepenuhnya menyembuhkan kembali semua struktur aslinya. Variasi terlihat dalam berbagai serat atau pola tulang. Radiografi yang jelas dengan lamina dura yang melebar atau konfigurasi tulang yang berubah. Faktor-faktor tertentu, seperti ukuran cacat atau tingkat cedera pada dasar stroma dapat berdampak pada regenerasi lengkap dari struktur jaringan asli. Boyne telah menunjukkan bahwa defek akan sembuh jika distimulasi oleh faktorfaktor induktif seperti bone morphogenetic protein. ${ }^{6}$

Faktor-faktor lain yang dapat mempengaruhi penyembuhan lesi periapikal meliputi faktor host yang melekat seperti leukopenia, gangguan suplai darah, nutrisi yang tidak memadai, kortikosteroid, dan penyakit sistemik lainnya. Misalnya, pasien dengan diabetes mellitus yang tergantung insulin memiliki tingkat penyembuhan yang secara signifikan lebih rendah setelah terapi saluran akar gigi dengan lesi apikal daripada pasien non diabetes. ${ }^{6}$ 


\section{SIMPULAN}

Perawatan endodontik non bedah pada gigi molar pertama rahang bawah kiri nekrosis pulpa dengan lesi periapikal menunjukan keberhasilan dengan terjadinya penyembuhan jaringan keras

\section{DAFTAR PUSTAKA}

1. Mendoza-Mendoza AC. Caleza-Jiménez, A. Iglesias-Linares B. Solano-Mendoza, YañezVico Rm. Endodontic treatment of large periapical lesions : An alternative to surgery. Edorium J Dent. 2015; 2:1-6. DOI: 10.5348/ D01-2015-1-CS-1

2. Croitoru IC, CrăiTToiu Ş, Petcu $\mathrm{CM}$, Mihăilescu OA, Pascu RM, Bobic AG, Agop Forna D, CrăiToiu MM. Clinical, imagistic and histopathological study of chronic apical periodontitis. Rom J Morphol Embryol. 2016; 57(2 Suppl): 719-728.

3. Holland R, Gomes JE Filho, Cintra LTA, Queiroz ÍOA, Estrela C. Factors affecting the periapical healing process of endodontically treated teeth. J Appl Oral Sci. 2017; 25(5): 465476. DOI: $10.1590 / 1678-7757-2016-0464$.

4. Mohammadi Z, Dummer PM. Properties and applications of calcium hydroxide in endodontics and dental traumatology. Int Endod J. 2011; 44(8): 697-730. DOI: 10.1111/j.13652591.2011.01886.x.

5. Mandhotra P, Goel M, Rai K, Verma S, Thakur V, Chandel N. Accelerated Non Surgical Healing of Large Periapical Lesions using different Calcium Hydroxide Formulations: A Case Series. Int J Oral Heal Medl Res. 2016; 3(4): 79-83.

6. Torabinejad M, Walton R. Endodontics Principles and Practice. $6^{\text {th }}$ ed. St. Louis. Elsevier Inc; 2020. p.14-327

7. Aksoy F. Outcomes of nonsurgical endodontic treatment in teeth with large periapical lesion. Ann Med Res.2019; 26(11): 2642-7. DOI: 10.5455/annalsmedres.2019.08.444

8. Dua KK, Atwal, PKK,Nonsurgical Healing of a Large Periapical Lesion Associated with a Tworooted Maxillary Lateral Incisor. CHRISMED J Health Res. 2018; 5(1): 48-50. DOI: $10.4103 /$ cjhr.cjhr $73 \quad 17$

9. Ildikó J. Márton, Csongor Kiss. Overlapping
Protective and Destructive Regulatory Pathways in Apical Periodontitis. JOE. 2013; 40(2): p. 155-163. DOI: 10.1016/j. joen.2013.10.036

10. Lin S, Kaufman AY, Ginesin O, Shimko T, Elbahary S, Wisblech D, Nissan J. Indications for root canal treatment in asymptomatic teeth with various radiographic findings: guidelines for general dental practice. Quintessence Int. 2019; 50(8): 612-623. DOI: 10.3290/j. gi.a42949.

11. Karunakaran JV, Abraham CS, Karthik AK, Jayaprakash N. Successful Nonsurgical Management of Periapical Lesions of Endodontic Origin: A Conservative Orthograde Approach. J Pharm Bioallied Sci. 2017; 9(Suppl 1): 246-251. DOI: 10.4103/jpbs.JPBS_100_17.

12. Moshari A, Vatanpour M, EsnaAshari E, Zakershahrak M, Jalali Ara A. Nonsurgical Management of an Extensive Endodontic Periapical Lesion: A Case Report. Iran Endod J. 2017 ; 12(1): 116-119. DOI: 10.22037/ iej.2017.24.

13. Holland et al. Factors affecting the periapical healing process of endodontically treated teeth. J Appl Oral Sci. 2017; 25(5): 465-76. DOI: 10.1590/1678-7757-2016-0464

14. Hargreaves KM, Berman LH. Cohen's pathways of the Pulp 12 $12^{\text {nd }}$ ed. Missouri: Elsevier Inc. 2020. p. 630-655

15. Gupta S, Kulkarni P, Bansal A, Jain A.NonSurgical Management of Periapical Lesion. IOSR-JDMSA. 2015; 14(8): 105-108.

16. Yue J, Wang $P$, Hong $Q$, Liao $Q$, Yan $L$, Xu W, Chen X, Zheng Q, Zhang L, Huang D. MicroRNA-335-5p Plays Dual Roles in Periapical Lesions by Complex Regulation Pathways. J Endod. 2017 Aug;43(8):13231328. DOI: 10.1016/.j.joen.2017.03.018.

17. Roda RS, Gettleman BH. Non surgical retreatment. $12^{\text {nd }}$ ed. Missouri: Elsevier Inc; 2020. p.175-184.

18. Santos Soares SM, Brito-Júnior M, de Souza FK, Zastrow EV, Cunha CO, Silveira FF, Nunes E, César CA, Glória JC, Soares JA. Management of Cyst-like Periapical Lesions by Orthograde Decompression and Long-term Calcium Hydroxide/Chlorhexidine Intracanal Dressing: A Case Series. J Endod. 2016; 42(7): 1135-41. DOI: 10.1016/j.joen.2016.04.021. 
19. Kusumadewi PR. Flare-up Endodontik Antar Kunjungan. [skripsi]. Denpasar; Udayana. 2018; h.1-35

20. Laukkanen, E., Vehkalahti, M.M. \& Kotiranta, A.K. Impact of type of tooth on outcome of nonsurgical root canal treatment. Clin Oral Invest 23. 2019 p. 11-4018 . DOI: $10.1007 / s 00784-$ 019-02832-0
21. Rotstein I, Ingle JI. Ingle's. Endodontics 7. $7^{\text {th }}$ ed. USA: PMHP USA Ltd. 2019. p.963-80

22. Verma N, Sangwan P, Tewari S, Duhan J. Effect of Different Concentrations of Sodium Hypochlorite on Outcome of Primary Root Canal Treatment: A Randomized Controlled Trial. J Endod. 2019; 45(4): 357-363. DOI: 10.1016/j.joen.2019.01.003. 